\title{
PRODUCTION OF STAR FRUIT ROOTSTOCKS FERTILIZED WITH DIFFERENT BORON DOSAGES
}

\author{
Clariana Xavier ${ }^{1} \&$ William Natale ${ }^{2}$
}

\begin{abstract}
${ }^{1}$ Universidade Estadual Paulista Júlio de Mesquita Filho.Campus Jaboticabal. E-mail: clarianavaladares@ yahoo.com.br
${ }^{2}$ Universidade Federal do Ceará. E-mail: natale@ufc.br
\end{abstract}

\begin{abstract}
Among the tropical fruits, star fruit stands out due to its flavor and nutritional properties. Nevertheless, the information on fertilization and nutrition of this fruit is still scarce. For this reason, this study aimed at assessing the effect of different boron dosages on star fruit rootstock growth. The experimental was randomized block design, consisting of five treatments of boron application $(0,1,2,3$, and $4 \mathrm{mg} \mathrm{dm}^{-3}$ ) and four replications. Star fruit rootstock did not respond to boron dosages applied to the substrate and hence it did not influence the parameters: stem diameter, plant height, the number of leaves, dry mass of sprout, dry mass of roots, total dry mass, and Dickson quality index (DQI). A boron dosage up to $4 \mathrm{mg} \mathrm{dm}^{-3}$ ( $800 \%$ of the recommended boron dose of $0.5 \mathrm{mg} \mathrm{dm}^{-3}$ ) did not produce symptoms of visual toxicity in the plant.
\end{abstract}

Keywords: Boron fertilization, Averrhoa carambola, micronutrient, seedling production

\section{PRODUÇÃO DE PORTA-ENXERTOS DE CARAMBOLEIRA ADUBADOS COM DIFERENTES DOSES DE BORO}

\section{RESUMO}

Dentre as frutas tropicais, destaca-se a da caramboleira devido ao seu sabor e propriedades nutricionais. Apesar disso, são escassas as informações sobre a adubação e a nutrição desta frutífera. $\mathrm{O}$ trabalho propôs avaliar o efeito de diferentes doses de boro sobre o crescimento de porta-enxerto de caramboleira. O delineamento utilizado foi em blocos casualizados, composto por tratamentos com cinco doses de boro $\left(0,1,2,3\right.$ e $\left.4 \mathrm{mg} \mathrm{dm}^{-3}\right)$ e quatro repetições. O porta-enxerto de caramboleira não respondeu às doses de boro aplicadas ao substrato e, portanto, não influenciou os parâmetros avaliados: diâmetro do caule; a altura das plantas; o número de folhas; a massa seca da parte aérea, das raízes e a total e o 
índice de qualidade de Dickson (IQD). A dose de até $4 \mathrm{mg} \mathrm{dm}^{-3}$ de B (800\% da dose recomendada de $0,5 \mathrm{mg}$ de B) que não produz sintomas de toxidez visuais na planta.

Palavras-chave: Adubação boratada, Averrhoa carambola, Micronutriente, Produção de mudas

\section{INTRODUCTION}

Star fruit tree (Averrhoa carambola L.) is an exotic plant native to Asia, typical of tropical regions (BASTOS, 2004). Due to its flavor, aroma, and nutritional properties such as vitamins A, C, and K, in addition to several amino acids, star fruit stands out among tropical fruits (FREITAS et al., 2011).

The main star fruit producing countries are Taiwan, Malaysia, and Brazil, with an estimated production varying from 3,000 to 40,000 tons of fruits (GOENAGA, 2007). Oliveira et al. (2009) estimate that the cultivated area with star fruits in Brazil is approximately 300 ha, located predominantly in the Southeastern region. In this sense, São Paulo State stands out in the national production of star fruit, with a volume of 3,700 tons of fruits negotiated in 2011 by the General Warehouses Company of São Paulo (Ceagesp) (AGRIANUAL, 2012).

The use of seeds for plant propagation should be used only for rootstock formation (BASTOS et al., 2007). Thus, star fruit is commercially propagated by grafting using budding or cleft techniques. Although the use of rootstocks is a common practice for different species, for which several studies can be found in the literature, few studies are related to rootstock formation for star fruit seedling production (BASTOS et al., 2007), as well as for rootstock management.

One of the essential steps in the process of rootstock formation for seedling production is the substrate choice. The substrate is defined as a natural or synthetic physical medium where plant roots grown in the absence of soil. This material must be free of pathogens, must present a good water retention capacity, a good drainage, a high cation exchange capacity, and a low cost (KÄMPT, 2000).

Rootstock and seedling production with an adequate nutritional status have a great importance since it defines the success of a star fruit orchard implantation, in addition to influencing the precocity of production and productive potential. In perennial crops, seedling quality is directly related to agricultural yield and high productivity, reflecting in the economic return on invested capital (FREITAS et al., 2011). Star fruit is a rustic plant (DONADIO et al., 2001), presenting a certain tolerance to few variations in nutrient concentrations (ROZANE et al., 2011). However, management and fertilization practices are important to provide the necessary nutrients to plants, maintaining the nutritional balance 
and leading to a good development and productivity.

Different authors have studied the influence of macronutrient fertilization on seedling production using substrates (BERNARDI et al., 2000; CARVALHO et al., 2000; BOAVENTURA et al., 2004). However, studies involving micronutrients have not received the same attention (MATTOS JÚNIOR et al., 2008).

Among the micronutrients, boron has an important role since it is directly related to meristematic growth, cell elongation, cell wall biosynthesis, functioning of the mebrane of the cell, auxin transport (IAA), carbohydrate metabolism, and nucleic acid synthesis (TARIQ \& MOTT, 2007), which makes this micronutrient essential for root growth, reflecting on shoot development of plants (YAMADA, 2000). Thus, boron deficiency affects plant tissue growth (MARSCHNER, 2012), while its excess causes toxicity characterized by generalized chlorosis and necrotic spots in the plant (MALAVOLTA et al., 1997).

Differences regarding boron requirements by crops are attributed to variations in cell wall chemical composition between species (MARSCHNER, 2012). Cell wall has about $90 \%$ of boron in its constitution and when plants are properly managed, more than $60 \%$ of the total boron may be in a soluble form (MENGEL \& KIRKBY, 2001).

Symptoms of boron deficiency and toxicity are related to its mobility, which is considered low or very limited in the phloem (MALAVOLTA et al., 1997). However, a recent study shows that boron mobility is quite variable among species (SOUZA et al., 2012).

Boron deficiency response is different from plant to plant depending on the species and cultivar assessed (GUPTA, 1993; BROWN \& SHELP, 1997), in addition to the physiology related to the plant response to low boron concentrations (DELL \& HUANG, 1997).

Differential tolerance of species and cultivars to boron excess has been reported in revision studies (GUPTA, 1993; DECHEN et al., 1999). However, no experimental data can be found relating the appropriate or toxic boron doses to star fruit rootstocks cultivated in substrates.

In the production of yellow passion fruit seedlings, Prado et al. (2006) observed that increased seedling growth was associated with a boron dose of $0.6 \mathrm{mg} \mathrm{dm}^{-3}$. However, higher doses caused a significant reduction in passion fruit seedling development. For bean, the appropriate and toxic boron doses were 2 and $4.4 \mathrm{mg} \mathrm{kg}^{-1}$, respectively. For corn, the appropriate boron dose was $4.7 \mathrm{mg} \mathrm{kg}^{-1}$ whereas the toxic dose was $8.7 \mathrm{mg} \mathrm{kg}^{-1}$ (FAGERIA, 2000).

The development of studies with borated fertilization aims to provide information on the 
appropriate boron concentration to rootstocks, contributing to a greater uniformity and velocity in seedling growth. The use of quality rootstocks for star fruit cultivation is related to the capacity to reduce the time to start the production, reducing the permanence time of seedlings in the nursery, which is reflected in the economic return on invested capital. Some studies have shown that boron fertilization on fruits such as peach (SOUZA et al., 2012) and passion fruit (PRADO et al., 2006) favors seedling growth. However, few studies assess its effects on star fruit rootstock production. Thus, this study aimed at appointing the effect of increasing boron doses on star fruit rootstock growth cultivated in the substrate.

\section{MATERIAL AND METHODS}

The experiment was conducted between September 2012 and February 2013 in a commercial seedling nursery located at the Sítio São João, Taquaritinga, in the state of São Paulo, Brazil, geographical coordinates of $21^{\circ} 44^{\prime} \mathrm{S}$ and $48^{\circ} 29^{\prime} \mathrm{W}$ and an altitude of $512 \mathrm{~m}$. The regional climate is classified as Cwa, i.e. a subtropical climate with summer rains and a relatively dry winter (KÖPPEN, 1948).

Star fruit (Averrhoa carambola L.) rootstocks were propagated via seeds on December 7, 2011. At the time of experiment installation, plants were one year and two months old. Star fruit rootstocks were fertilized three times before experiment installation with $1 \mathrm{~g}$ of the formula 8-28-16 $\left(\mathrm{N}_{-}-\mathrm{P}_{2} \mathrm{O}_{5}-\right.$ $\mathrm{K}_{2} \mathrm{O}$ ) per plant at each application, which was performed 30, 90, and 150 days after emergence.

The experimental design was a randomized block design, consisting of five boron doses $(0,1,2$, 3 , and $4 \mathrm{mg} \mathrm{dm}^{-3}$ ) and four replications. Each plot was composed with three plants (one rootstock per bag), totaling 60 star fruits. For dose definition, a reference boron dose of $0.5 \mathrm{mg} \mathrm{dm}^{-3}$ was used, as suggested by Malavolta (1980) for experiments in pots. Boron doses of 0, 1, 2, 3, and $4 \mathrm{mg} \mathrm{dm}^{-3}$ corresponded to $0,11.76,23.53,35.29$, and $47.06 \mathrm{mg}$ of boric acid $\left(\mathrm{H}_{3} \mathrm{BO}_{3}\right.$ with $17 \%$ of boron), respectively, per experimental unit and were applied in a solid form on the substrate surface in each bag. The initial boron content was $0.3 \mathrm{mg} \mathrm{L}^{-1}$ in the substrates that did not receive boron application.

Rootstocks were cultivated in polyethylene bags $(18 \times 30 \mathrm{~cm})$ with a volume of $2 \mathrm{dm}^{3}$ filled with composted pine bark and expanded vermiculite as substrate (Multiplant Citrus ${ }^{\circledR}$ ). The bags were placed on benches without spacing between them. The analysis of substrate nutrient content used to fill the bags was carried out at the Agronomic Institute of Campinas (Table 1).

Table 1. Chemical characteristics and nutrient concentrations in the substrate used in the experiment (Taquaritinga, SP, Brazil, 2012). 


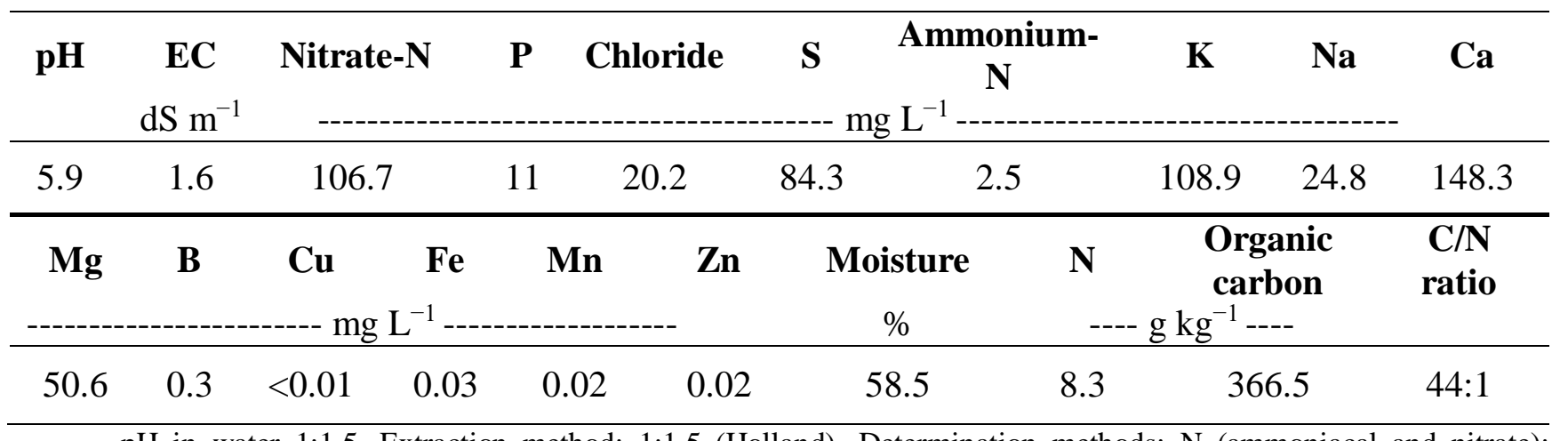

$\mathrm{pH}$ in water 1:1.5. Extraction method: 1:1.5 (Holland). Determination methods: $\mathrm{N}$ (ammoniacal and nitrate): distillation; K, Ca, Mg, P, S, Cu, Fe, Mn, and Zn: ICP-OES; B: hot water. Moisture $65^{\circ} \mathrm{C}$. Results for total carbon and nitrogen contents were obtained by a CNS elemental analyzer (ELEMENTAR CNS). Source: Agronomic Institute of Campinas (RAIJ et al., 1996).

Substrate $\mathrm{pH}$ value (5.9) was within the range where a greater nutrient availability can be found when compared to the range of interpretation of analysis results proposed by the European Committee for Standardization, which indicates a pH between 5.5 and 6.5 (BAUNGARTEN, 2002).

Rootstocks were irrigated with water from a semi-artesian well by means of a micro-sprinkler system activated daily in order to avoid substrate drenching, thus avoiding nutrient leaching. The seedling nursery was covered with a polypropylene screen with $30 \%$ shading in order to provide protection to plants against the high incidence of sunlight and decrease evapotranspiration process.

Before treatment application, two star fruits from the same batch were collected at random to assess the initial biometric parameters. Plants were divided into shoot and roots, being subsequently dried in a forced ventilation oven at 65 to $70^{\circ} \mathrm{C}$ until constant weight to determine dry mass.

The selected star fruits presented the following characteristics: average height of $59.3 \pm 0.2 \mathrm{~cm}$, average stem diameter of $4.8 \pm 0.2 \mathrm{~mm}$, average number of leaves of $11 \pm 1$, shoot dry mass of $4.9 \pm 0.5$ $\mathrm{g}$, and root dry mass of 7.8 $\pm 1.1 \mathrm{~g}$. Plant height was measured from the base of the rootstock to the apical bud by using a metric ruler. Stem diameter was determined with a digital caliper at $15 \mathrm{~cm}$ from the base of the rootstock (graft union) and the number of leaves was obtained by counting all plant leaves.

Control of weeds, diseases, and pests, in addition to all necessary cultural practices, were carried out according to the usual practices for seedling production adopted in the commercial nursery.

During the experimental period, two fertilizer applications were performed with $1 \mathrm{~g}$ of the formula 10-10-10 $\left(\mathrm{N}-\mathrm{P}_{2} \mathrm{O}_{5}-\mathrm{K}_{2} \mathrm{O}\right)$. The first application was carried out after boron application and the second 60 days after the first application.

Measurements of plant height, stem diameter, and the number of leaves, which are biological 
parameters indicative of plant growth, were conducted 170 days after treatment application, 590 days after sowing, recommended time for star fruit grafting by budding or cleft. After biometric data collection, the leaf chlorophyll content reading, expressed in SPAD (Soil Plant Analysis Development) values, was performed by means of a chlorophyll meter Minolta SPAD-502 in the medial region of the leaf blade of the third leaf from the apex to the branch base. In adult star fruit trees, chlorophyll content determination with SPAD is recommended to be carried out in the sixth newly-mature leaf when in the full flowering time (PRADO \& NATALE, 2004). However, no indication can be found in the literature regarding the appropriate leaf for chlorophyll content determination with SPAD in seedlings or young plants of star fruits.

Subsequently, plants were collected, separated into shoot and roots, and washed initially with running water, then with neutral detergent at $0.1 \%$ concentration, after that with $0.3 \%(\mathrm{v} / \mathrm{v}) \mathrm{HCl}$ solution, and finally with distilled and deionized water. After washing, plants were dried in a forced air circulation oven at 65 to $70{ }^{\circ} \mathrm{C}$ until constant mass and weighed in an analytical balance to obtain shoot, root, and total dry mass.

With the data obtained, the Dickson quality index (DQI), an integrated morphological measure used to assess seedling quality, was calculated using the following equation (DICKSON et al., 1960, cited by DIAS et al., 2012): DQI = TDM / [(PH / SD) + (RDM / SDM $)$, where TDM is the total dry mass $(\mathrm{g}), \mathrm{PH}$ is the plant height $(\mathrm{cm}), \mathrm{SD}$ is the stem diameter $(\mathrm{mm}), \mathrm{RDM}$ is the root dry mass $(\mathrm{g})$, and SDM is the shoot dry mass $(\mathrm{g})$.

The data were submitted to the analysis of variance, which was performed by using the software AgroEstat (BARBOSA \& MALDONADO Jr, 2014).

\section{RESULTS AND DISCUSSION}

The increasing boron doses applied to the substrate did not influence the parameters related to star fruit rootstocks growth assessed in this study (Table 2). No visual symptoms of abnormalities caused by boron excess were observed. According to Malavolta et al. (1997), these symptoms are characterized by generalized chlorosis and necrotic spots in the plants (Figure 1). 


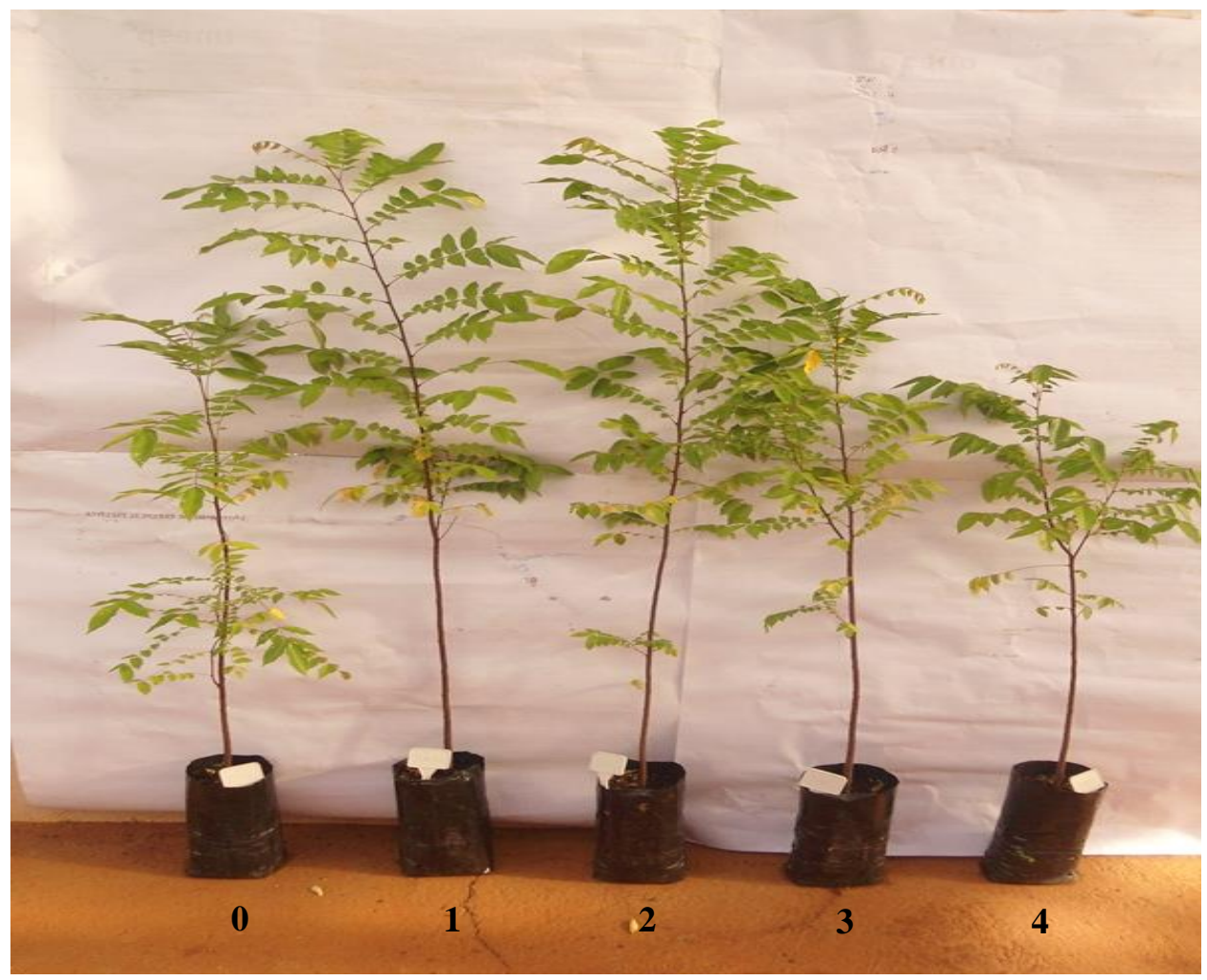

Figure 1. Star fruit (Averrhoa carambola L.) rootstocks in the treatments with boron doses of $0,1,2,3$, and $4 \mathrm{mg} \mathrm{dm}^{-3}$ (Taquaritinga, SP, Brazil, 2013).

Mattos Júnior et al. (2008) observed visual symptoms of boron phytotoxicity in citrus rootstocks cultivated in the substrate with $3 \mathrm{~g} \mathrm{~m}^{-3}$ of boron. In guava seedlings, Salvador et al. (2003) observed symptoms of visual abnormalities caused by boron excess. These symptoms started 120 days after transplantation to pots and were associated with a dose of $3.0 \mathrm{mg} \mathrm{L}^{-1}$ of nutrient solution.

Rozane et al. (2011) studied star fruit rootstocks from the cultivar Malaysia and did not observe a significant effect of treatments on height, stem diameter, the number of leaves, leaf area, and dry matter of stem mass in the nutrient solutions tested. The nutrient solution with a boron dose of $0.2 \mathrm{mg} \mathrm{L}^{-1}$ was better when compared to a dose of $0.5 \mathrm{mg} \mathrm{L}^{-1}$ for leaves, roots, and whole-plant dry mass production.

However, cultivation conditions (substrate and nutrient solution) are different and it must be taken into consideration. In general, increased speed of growth and development of plants are studied in soilfree cultivation, allowing a better control of nutrient ratios such as nutrient solutions (ROZANE et al., 2011) since the concentration of elements in the nutrient solution is proportional to that found close the plant roots (ADAMS, 1994).

Lucena (1997) pointed out that the results obtained in nutrient solution are more accurate when 
compared to those obtained in the cultivation with soil, in addition to representing a lower cost in terms of chemical analysis. However, soil-free cultivation method has some disadvantages such as a high cost of installing the systems, need for permanent monitoring of system's operation, mainly the supply of electricity, and control of nutrient solution (CASTELLANE \& ARAÚJO, 1994).

In this study, the average height of plants was $104.8 \mathrm{~cm}$ (Table 2), not differing $(\mathrm{p}>0.05)$ as a function of boron doses applied to the substrate. This result is similar to that obtained by Zanão Júnior et al. (2014), who also did not observe significant differences in the height of roses cultivated in substrates with different boron doses $\left(0,1,4,8\right.$, and $\left.16 \mathrm{mg} \mathrm{kg}^{-1}\right)$ and an initial boron content of $0.2 \mathrm{mg} \mathrm{L}^{-1}$.

Due to the lack of studies related to star fruit, this study was based on the comparison with different species, but with the same class of dicotyledonous since they require a greater amount of boron when compared to monocotyledonous species (BROWN et al., 1992).

For seedlings of yellow passion fruit, Prado et al. (2006) observed an increased average plant height with a boron dose of $0.6 \mathrm{mg} \mathrm{dm}^{-3}$. In peach seedlings, Souza et al. (2012) observed an increase of $11.23 \%$ and $21.10 \%$ in plant height at 30 and 60 days, respectively, after boron application $(0.75 \mathrm{mg}$ of boron per seedling) via soil.

The amount of boron applied to the substrate did not influence rootstock stem diameter (Table 2). However, the values found after 170 days were higher than the $6 \mathrm{~mm}$ considered as appropriate for performing grafting in this species (ROZANE et al., 2013). According to Melo et al. (2005), stem diameter is a morphological characteristic of rootstock that determines the graft union and the success in the seedling formation process. Oliveira et al. (2010), when using different boric acid doses $(0,3,6,9$, $\mathrm{mg} \mathrm{dm}{ }^{-3}$ of boron) in passion fruit seedlings cultivated in substrate, observed that the stem diameter was not influenced by nutrient doses.

According to Rozane et al. (2013), a probable explanation for the non-influence of this micronutrient in the assessed parameter would be the shading caused by star fruit growth, in addition to the reduced spacing for the plants. However, in these authors' study, as well as in the present study, the spacing used was that indicated for commercial star fruit cultivation, indicating that plant development was not limited by boron supply.

No effect of borated fertilization was observed on the number of leaves (Table 2). Oliveira et al. (2010) found similar results in passion fruit seedlings. However, Souza et al. (2012) observed increases of $6.33 \%$ and $8.66 \%$ in the number of leaves at 30 and 60 days, respectively, after applying boron $(0.75$ $\mathrm{mg}$ of boron per seedling) via soil in an experiment with peach seedlings. 
Table 2. Average values \pm standard deviation of plant height $(\mathrm{PH})$, stem diameter (SD), number of leaves (NL), shoot dry mass (SDM), roots dry mass (RDM), total dry mass (TDM), and Dickson quality index (DQI) of star fruit rootstocks fertilized with different boron doses (Taquaritinga, SP, Brazil, 2013).

\begin{tabular}{lccccccc}
\hline Boron doses & PH & SD & NL & SDM & RDM & TDM & DQI \\
$--\mathrm{mg} \mathrm{dm}^{-3}-$ & $---\mathrm{cm} \mathrm{---}$ & $---\mathrm{mm}---$ & & & & & \\
\hline 0 & $102.37 \pm$ & $7.77 \pm$ & $35.32 \pm$ & $22.67 \pm$ & $21.28 \pm$ & $43.96 \pm$ & $0.31 \pm$ \\
& 4.77 & 0.15 & 2.70 & 1.05 & 0.87 & 1.23 & 0.15 \\
1 & $108.90 \pm$ & $7.91 \pm$ & $33.17 \pm$ & $21.91 \pm$ & $20.23 \pm$ & $42.14 \pm$ & $0.29 \pm$ \\
& 4.15 & 0.20 & 2.54 & 1.43 & 0.86 & 2.25 & 0.11 \\
2 & $102.90 \pm$ & $7.53 \pm$ & $35.40 \pm$ & $21.99 \pm$ & $20.39 \pm$ & $42.38 \pm$ & $0.29 \pm$ \\
& 4.81 & 0.13 & 1.90 & 0.46 & 0.72 & 0.89 & 0.25 \\
3 & $108.35 \pm$ & $8.17 \pm$ & $37.50 \pm$ & $23.55 \pm$ & $23.28 \pm$ & $46.83 \pm$ & $0.33 \pm$ \\
& 5.08 & 0.09 & 1.36 & 0.87 & 0.76 & 1.34 & 0.20 \\
4 & $101.50 \pm$ & $7.62 \pm$ & $34.00 \pm$ & $22.74 \pm$ & $21.20 \pm$ & $43.95 \pm$ & $0.31 \pm$ \\
& 2.93 & 0.28 & 2.76 & 1.29 & 1.28 & 2.57 & 0.31 \\
\hline F-test & $0.51^{\mathrm{ns}}$ & $1.47^{\mathrm{ns}}$ & $0.40^{\mathrm{ns}}$ & $0.30^{\mathrm{ns}}$ & $1.38^{\mathrm{ns}}$ & $0.88^{\mathrm{ns}}$ & $0.45^{\mathrm{ns}}$ \\
MSD & 22.27 & 0.93 & 11.68 & 5.44 & 4.65 & 8.97 & 1.11 \\
$(5 \%)$ & $9.4 \%$ & $5.3 \%$ & $14.8 \%$ & $10.7 \%$ & $9.7 \%$ & $9.1 \%$ & $16.1 \%$ \\
CV & & & & & & & \\
\hline
\end{tabular}

$\mathrm{N}$ (number of observations) $=4$.

ns - not significant.

Rootstock shoot dry mass was not affected by boron doses applied to the substrate (Table 2). Similar results were found by Rodrigues et al. (2009) when assessing different cultivars of castor seedlings at boron doses of $0,0.25,0.50,0.75$, and $1.0 \mathrm{mg} \mathrm{kg}^{-1}$ in the substrate. In a study assessing passion fruit seedlings, Prado et al. (2006) observed that shoot dry matter production was associated with a boron dose close to $0.5 \mathrm{mg} \mathrm{dm}^{-3}$.

Regarding root dry mass (RDM), it is known that boron is directly related to root development by promoting a higher meristem growth (YAMADA, 2000). However, in this study, boron doses applied to the substrate did not increase RDM (Table 2). Oliveira et al. (2010) observed a positive effect of boron doses on root dry mass in passion fruit seedlings. In this case, boron doses higher than $4.16 \mathrm{mg} \mathrm{dm}^{-3}$ applied to the substrate promoted an increase in this parameter.

On the other hand, Fageria (2000) observed that the appropriate boron dose for root system development varies according to the crop. This author found an appropriate range from 0.4 to $2.9 \mathrm{mg}$ $\mathrm{kg}^{-1}$ for wheat, rice, and corn cultivated in pots. Wheat cultivation required a higher boron concentration for root development when compared to rice and corn.

Contrary to the studies up to now presented here on the effect of increasing boron doses on crop 
development, Freitas et al. (2006) assessed the effects of boron-induced deficiency on Passiflora edulis (passion fruit) plants and did not find a significant reduction in root dry mass. For rubber tree rootstock, Moreira et al. (2006) studied different boron doses and found that high doses ( $8 \mathrm{mg} \mathrm{dm}^{-3}$ of boron) did not affect the number of roots.

The lack of response of rootstock dry matter regarding the increasing levels of borated fertilization (Table 2) suggests that the range of boron doses applied in this case may have provided only a "luxury" consumption of this micronutrient. According to Franco \& Prado (2006), the lack of significance of some nutrient solutions on dry matter mass production of guava seedlings is related to the concentrations of solution used, which were sufficient to meet the plant nutritional requirements, not leading to changes in this parameter.

When considering the Dickson quality index (DQI), the results of this study demonstrated that increasing levels of boron fertilization did not influence growth parameters of star fruit rootstock. DQI is an index traditionally used in the seedling production of forest species. However, the same characteristics that compose this index are important for the production of fruit tree seedlings. According to Gomes et al. (2003), the higher the DQI, better the seedling quality produced.

A possible explanation for the lack of response of star fruit rootstocks to treatments may be related to the contribution of boron from the substrate in a sufficient amount for the adequate plant development until the assessment stage. Another possible explanation for these results would be related to the plant age, which was 1 year and 2 months old when the study started, and could already contain in their tissues accumulated concentrations of boron sufficient for the initial plant growth.

\section{CONCLUSIONS}

Star fruit rootstock does not respond to boron doses of $0,1,2,3$, and $4 \mathrm{mg} \mathrm{dm}^{-3}$ applied to the substrate. Therefore, these doses do not influence biometric parameters such as plant height, stem diameter, the number of leaves, shoot, root, and total dry mass, and Dickson quality index.

Boron doses up to $4 \mathrm{mg} \mathrm{dm}^{-3}$ ( $800 \%$ of the recommended boron dose of $0.5 \mathrm{mg} \mathrm{dm}^{-3}$ ) do not produce symptoms of visual toxicity in the plant, evidencing the high tolerance of star fruit rootstock.

Further studies are needed using boron-free substrates, in addition to more sequenced assessments accompanying the initial development and growth stages until the grafting time. 


\section{REFERENCES}

ADAMS, P. 1994. Nutrition of greenhouse vegetables in NFT an hydroponic systems. Acta Horticulturae, Wageningen, n. 361, p. 254-257.

AGRIANUAL. 2012. Anuário da Agricultura Brasileira. São Paulo: FNP Consultoria \& Comércio.

BARBOSA, J. C.; MALDONADO Jr, W. 2014. AgroEstat: sistema para análises estatísticas de ensaios agronômicos. Versão 1.1.0.711. Jaboticabal: Departamento de Ciências Exatas.

BASTOS, D. C. A. 2004. Cultura da carambola. Revista Brasileira de Fruticultura, Jaboticabal, v.26, n.2, p.1-2.

BASTOS, D. C.; PIO, R.; SCARPARE FILHO, J. A.; LIBARDI, M. N.; ALMEIDA, L. F. P.; ENTELMANN, F. A. 2007. Diferentes substratos na produção de porta-enxertos de caramboleira. Ciência e Agrotecnologia, Lavras, v.31, n.2, p.312-316.

BAUNGARTEN, A. 2002. Methods of chemical and physical evaluation of substrates for plants. In A. M. C. FURlani; O. C. BAtAGliA; M. F. ABREU; C. A. ABREU; P. R. FURLANI; J. A. QUAGGIO; K. MINAMI (Eds.), Caracterização, manejo e qualidade de substratos para produção de plantas (p.17-28). Campinas: Instituto Agronômico.

BERNARDI, A.C.C.; CARMELLO, Q.A.C.; CARVALHO, S.A. 2000. Macronutrientes e mudas de citros cultivadas em vasos em resposta à adubação NPK. Scientia Agricola, Piracicaba, v.57, p. 761-767.

BOAVENTURA, P.R.R.; QUAGGIO, J.A.; ABREU, M.F.; BATAGLIA, O.C. 2004. Balanço de nutrientes na produção de mudas cítricas cultivadas em substrato. Revista Brasileira de Fruticultura, Jaboticabal, v. 26, n. 2, p.300-305.

BROWN, P. H.; PICCHIONI, G.; JENKIN, M.; HU, H. 1992. Use of ICP-MS and $1^{0 \mathrm{~B}}$ to trace the movement of boron in plants and soil. Communications in Soil Science and Plant Analysis, New York, v.23, n.17-20, p.2781-2807.

BROWN, P.H. \& SHELP, B.J. 1997. Boron mobility in plants. Plant Soil, The Hague,193:85-101.

CARVALHO, S.A.; MATTOS JUNIOR, D.; SOUZA, M. 2000. Efeitos do $\mathrm{KNO}_{3}$ nos teores de micronutrientes na matéria seca total de porta-enxertos cítricos produzidos em bandejas. Bragantia, Campinas, v. 49, p. 89-94.

CASTELLANE, P.D.; ARAÚJO, J.A.C. 1994. Cultivo sem solo: hidroponia. Jaboticabal: FUNEP/UNESP, 43p.

DECHEN, A.R.; FURLANI, A.M.C. \& FURLANI, P.R. 1999. Tolerância e adaptação de plantas aos estresses nutricionais. In: SIQUEIRA, J.O.; MOREIRA, F.M.S.; LOPES, A.S.; GUILHERME, L.R.G.; FAQUIN, V.; FURTINI NETO, A.E. \& CARVALHO, J.G., eds. Inter-relação fertilidade, biologia do solo e nutrição de plantas. Lavras, Sociedade Brasileira de Ciência do Solo/Universidade Federal de Lavras, p.337-361.

DELL, B. \& HUANG, L.B. 1997. Physiological response of plants to low boron. Plant Soil, The Hague, v.193, p.103-120.

DIAS, M. J. T.; SOUZA, H. A. DE; NATALE, W.; MODESTO, V. C.; ROZANE, D. E. 2012. Adubação com nitrogênio e potássio em mudas de goiabeira em viveiro comercial. Semina: ciências agrárias, Londrina, v.33, n.6, p.2837-2848.

DICKSON, A.; LEAF, A. L.; HOSNER, J. F. 1960. Quality appraisal of white spruce and white pine seedling stock in nurseries. The Forest Chronicle, Mattawa, v.36, n.1, p.10-13.

DONADIO, L. C.; SILVA, J. A. A.; ARAÚJO, P. S. R.; PRADO, R. M. 2001. Caramboleira (Averrhoa carambola L.). Jaboticabal: Sociedade Brasileira de Fruticultura, 81 p.

FAGERIA, N. K. 2000. Níveis adequados e tóxicos de boro na produção de arroz, feijão, milho, soja e trigo em solo de cerrado. Revista Brasileira de Engenharia Agrícola Ambiental, Campina 
Grande, v.4, n.1, p.57-62.

FRANCO, C.F.; PRADO, R.M. 2006. Uso de soluções nutritivas no desenvolvimento e no estado nutricional de mudas de goiabeira: macronutrientes. Acta Scientiarum. Agronomy, Maringá, v.28, 296 p.199-205.

FREITAS, M. S. M.; MONNERAT, P. H.; PINHO, L. G. R.; CARVALHO, A. J. C. 2006. Deficiência de macronutrientes e boro em maracujazeiro-doce: qualidade dos frutos. Revista Brasileira de Fruticultura, Jaboticabal, v.28, n.3, p.492-496.

FREITAS, N.; PRADO, R. M.; ROZANE, D. E.; TORRES, H.; AROUCA, M. B. 2011. Marcha de absorção de nutrientes e crescimento de mudas de caramboleira enxertada com a cultivar nota-10. Semina: ciências agrárias, Londrina, v.32, n.4, p.1231-1242.

GOENAGA, R. 2007. Yield and fruit quality traits of carambola cultivars grown at three locations in Puerto Rico. HortTechnology, Alexandria, v.17, p.604-607.

GOMES, J. M.; COUTO, L.; LEITE, H. G.; XAVIER, A; GARCIA, S. L. R. 2003. Crescimento de mudas de Eucalyptus grandis em diferentes tamanhos de tubetes e fertilização N-P-K. Revista Árvore, Viçosa, v.27, p.113-127.

GUPTA, U. C. 1993. Boron and its role in crop production. Boca Raton: CRC Press, 237 p.

KÄMPT, A. N. 2000. Produção comercial de plantas ornamentais. Guaíba: Agropecuária.

KÖPPEN, W. 1948. Climatologia: con um estúdio de los climas de la Tierra. México: Fondo de Cultura Economica.

LUCENA, J.J. 1997. Methods of diagnosis of mineral nutrition of plants: a critical review. Acta Horticulturae, Wageningen, v.448, p.179-182.

MALAVOLTA, E. 1980. Elementos de nutrição mineral de plantas. 3. ed. São Paulo: Ceres.

MAlavoltA, E.; VITTI, G. C.; OLIVEIRA, S. A. 1997. Avaliação do estado nutricional das plantas: princípios e aplicações. 2. ed. Piracicaba: POTAFÓS.

MARSCHNER, H. 2012. Mineral nutrition of higher plants. 3 ed. San Diego: Academic Press.

MATTOS JÚNIOR, D.; QUAGGIO, J. A.; CARVALHO, S. A.; ABREU, M. F. 1995. Substratos para a produção de mudas cítricas em recipientes: caracterização da toxicidade de boro. Laranja, Cordeirópolis, v.16, p.255-262.

MATTOS JÚNIOR, D.; BOARETTO, R. M.; CORRÊA, E. R. L.; ABREU, M. F.; CARVALHO, S. A. 2008. Disponibilidade de boro em substrato para produção de porta-enxertos de citros em fase de sementeira. Bragantia, Campinas, v.67, n.4, p.983-989.

MELO, A. S. D.; GOIS, M. P. P.; BRITO, M. E. B.; VIÉGAS, P. R. A.; ARAÚJO, F. P. D.; MÉLO, D. L. M. F. D.; MENDONÇA, M. D. C. 2005. Umbuzeiro rootstocks development as an answer for fertilization with nitrogen and phosphorous. Ciência Rural, Santa Maria, v. 35, n.2, p. 324-331.

MENGEL, K.; KIRKBY, E. A. 2001. Principles of plant nutrition. Dordrecht: Kluwer Academic Publishers. 849p.

MOREIRA, A. et al. 2006. Fontes e doses de boro em porta-enxertos de seringueira. Pesquisa Agropecuária Brasileira, Brasília, v. 41, n. 8, p. 1291-1298.

OLIVEIRA, M. T. R.; BERBERT, P. A.; VIEIRA, H. D.; THIÉBAUT, J. T. L.; CARLESSO, V. O.; PEREIRA, R. C. 2009. Avaliação do vigor de sementes de carambola em função da secagem e do armazenamento. Revista Brasileira de Engenharia Agrícola e Ambiental, Campina Grande, v. 13, n. 4, p. 477-482.

OLIVEIRA, L. A. A.; SILVA, K. B. DA; TOSTA, M. S.; GUIMARÃES, A. A.; SILVA, R. M. da. 2010. Doses de sulfato de zinco e ácido bórico na produção de mudas de maracujazeiro-amarelo. Revista Verde de Agroecologia Desenvolvimento Sustentável, Pombal, v.5, n.3, p.24-31.

PRADO, R. M.; NATALE, W. 2004. Leaf sampling in carambola trees. Fruits, Paris, v.59, n.4, p.261- 
269.

PRADO, R. M.; NATALE, W.; ROZANE, D. E. 2006. Níveis críticos de boro no solo e na planta para cultivo de mudas de maracujazeiro-amarelo. Revista Brasileira de Fruticultura, Jaboticabal, v. 28, n. 2, p. 305-309.

RAIJ, B. VAN; CANTARELLA, H.; QUAGGIO, J. A.; FURLAN, A. M. C. 1996. Recomendações de adubação e calagem para o Estado de São Paulo. Campinas: Instituo Agronômico de Campinas.

RODRIGUES, H. C. A.; CARVALHO, S. P.; SOUZA, H. A.; JESUS, A. M. S. 2009. Crescimento de cultivares de mamoneira em função da aplicação de boro, durante a formação de mudas. Scientia Agraria, Londrina, v.10, n.5, p.377-382.

ROZANE, D. E.; PRADO, R. M.; NATALE, W.; FRANCO, C. F. 2011. Crescimento, teor e acúmulo de nutrientes em hipobiotos de caramboleiras, cultivados em diferentes soluções nutritivas. Revista Ceres, Viçosa, v.58, n.3, p.366-372.

ROZANE, D. E.; PRADO, R. M.; NATALE, W.; ROMUALDO, L. M.; FRANCO, C. F. 2013. Caracterização biométrica e acúmulo de nutrientes em porta-enxertos de caramboleira cultivada em solução nutritiva. Revista de Ciência Agronômica, Fortaleza, v.44, n.3, p.426-436.

SALVADOR, J. O.; MOREIRA, A.; MALAVOLTA, E.; CABRAL, C. P. 2003. Influência do boro e do manganês no crescimento e na composição mineral de mudas de goiabeira. Ciência e Agrotecnologia, Lavras, v. 27, n. 2, p. 325-331.

SOUZA, J. A.; CANESIN, R. C. F. S.; BUZETTI, S. 2012. Mobilidade de boro em mudas de pessegueiro. Revista Brasileira de Fruticultura, Jaboticabal, v.34, n.3, p.930-935.

TARIQ, M.; MOTT, C. J. B. 2007. Effect of Boron on the behavior of nutrients in soil-plant systems - a review. Asian Journal of Plant Sciences, Faisalab, v.6, p.195-202.

YAMADA, T. 2000. Boro: será que estamos aplicando a dose suficiente para o adequado desenvolvimento das plantas? Piracicaba: POTAFOS. $20 \mathrm{p}$.

ZANÃO JÚNIOR, L. A. Z.; CARVALHO-ZANÃO, M. P.; LÚCIO, R.; FONTES, F.; GROSSI, J. A. S. 2014. Produção e qualidade de rosas em razão de doses de boro aplicadas no substrato. Revista Brasileira de Ciência do Solo, Viçosa, v.38, n.2, p.524-531. 